\title{
The Determinants of Financial Inclusion in Egypt
}

\author{
Abeer Rashdan ${ }^{1} \&$ Noura Eissa ${ }^{1}$ \\ ${ }^{1}$ Faculty of Economics and Political Science FEPS, Future University in Egypt FUE, New Cairo, Egypt \\ Correspondence: Noura Eissa, Future University in Egypt FUE, Faculty of Economics and Political Science FEPS, \\ 90th St, First New Cairo, Cairo Governorate 11835. E-mail: noura.eissa@ fue.edu.eg
}

Received: August 27, 2019

Accepted: October 3, 2019

Online Published: October 21, 2019

doi:10.5430/ijfr.v11n1p123

URL: https://doi.org/10.5430/ijfr.v11n1p123

\begin{abstract}
Recently, Egypt has prioritized financial inclusion in its monetary reform agenda. The objective of this paper is to examine the determinants of financial inclusion in Egypt using the World Bank's Global Findex 2017 database to conduct a logistic regression. Empirical results prove that there is no significant relationship between gender and the level of financial inclusion in Egypt, whereas, richer, more educated and older individuals are more strongly included in the financial system. The results reveal that the main barrier to financial inclusion is actually a lack of money; which hinders opening a formal account, savings account or credit account. Through possible policy measures, the paper recommends the need for a progressive approach to robust financial literacy and awareness in order for a positive economic growth role of financial inclusion to emerge in the Egyptian economy.
\end{abstract}

Keywords: financial inclusion, financial literacy, economic development, financial determinants

JEL Classification: G1, G21, G28, J16

\section{Introduction}

Financial inclusion, an enabler of economic growth, is a policy priority for most governments with emerging economies. Financial systems are the basic building blocks that facilitate and maintain economic growth in any economy. Within a theoretical framework, financial inclusion targets the efficient allocation of capital funds by mobilizing savings and managing risks, thus decreasing the level of inequality and reducing poverty levels. Financial inclusion is recognized as one of the main pillars of the global millennium development goals, specifically in heavily cash dependent societies (Kapoor, 2013). The definition of financial inclusion can be extracted from the term itself, with "inclusion" meaning that an individual is included in the system; that the individual has an account at a formal financial institution, the opportunity to save and borrow money formally, contract insurance and use payment services. Financial inclusion can favour disadvantaged people, allowing them to increase their income (Bruhn and Love, 2014). For instance, access to financial tools empowers women, entrepreneurs involved in small and medium sized enterprises (SMEs), and individuals involved in the informal sector, allowing them to invest in their education or financial projects and fully utilize their resources (Demirguc-Kunt and Klapper, 2015). Financial inclusion gives people access to the financial tools that allow them to invest in their education or become entrepreneurs. Zins and Weill confirm that "in the absence of inclusive financial systems, poverty traps can emerge and hamper economic development" (2016, p.46).

The Central Bank of Egypt (CBE) has played role in promoting and coordinating financial inclusion and considers it a strategic objective. In fact, financial inclusion is considered a "national priority", as dictated by one of the agendas of Egypt's Sustainable Development Strategy (SDS): Egypt's Vision 2030 (Financial Inclusion in Egypt, 2017). The move towards financial inclusion is important since strong financial penetration is directly linked to lower rates of poverty, unemployment, tax evasion, and financial crime such as money laundering. The real productive capacity coming from neglected groups such as the informal sector, micro-businesses, the women's sector, and the uneducated sector, becomes visible in the financial system via financial inclusion. The Egyptian government's budget is, in return, not deprived of tax revenues coming from these businesses, which increases the number of banks' clients, whether individuals, families or businesses, strengthening the control of policymakers over their policies and instruments such as interest rates. Financial inclusion could attract remittances, as it eases the transfer of funds from abroad. The banks depend on financial inclusion, since banks require customers' funds for re-investment and bank 
liquidity and because the charges on bank services rendered to customers form part of their overall profitability. Other gains from financial inclusion include improved household consumption and female empowerment.

The objective of this paper is to explore the relationship between the determinants of financial inclusion in Egypt and the financial inclusion indicators. The paper links the three main indicators (dependent variables) of financial inclusion in any economy: (a) ownership of a bank account; (b) saving in a bank account; and (c) using bank credit, and between the individual determinants that affect such indicators. The individual determinants are interchangeably used as explanatory variables or independent variables. With this aim, data from the World Bank's Global Findex database is used, and its descriptive statistics sample analysed to build an economic model specifically for Egypt that estimates and assesses the impact of individual characteristics on financial inclusion indicators. Recommendations and solutions with a progressive approach are thoroughly discussed.

\section{Literature Review}

\subsection{Financial Inclusion as a Concept in Literature}

The term financial inclusion is a dynamic term, developed recently, and continuing to develop as more research engages with the topic. Financial inclusion has certain necessary elements: it is a process with access for low income financially excluded groups that offers access to financial services. Awad and Eid (2018) define financial inclusion as a convenient and reasonable cost delivery process of financial services for low-income groups. The OECD states that financial inclusion is an affordable, easily accessible process including a wide range of regulated financial products and services. Financial inclusion should enhance financial awareness and financial education, while adding value to economic and social inclusion (Atkinson and Messy, 2013). A more specific definition of financial inclusion is introduced by Lenka and Bariq (2018): financial inclusion is a process that involves financial access to financially excluded groups in terms of financial services such as savings, payments, credit and internet banking. In summary, a healthy and effective financial inclusion process should fulfil certain criteria, including the existence of stable financial institutions accompanied by regulatory bodies, ease of access to finance for all individuals especially financially excluded groups, and long term sustainability of financial intermediaries in terms of offering premium financial products that match the needs of various groups (Mohieldin et al., 2011). As stated, financial inclusion involves increasing the number of, mostly poor, individuals who have access to formal financial services via formal bank accounts. Economist P. K. Ozilil states that financial inclusion should be looked upon as a series of steps, starting with the greater use of digital finance, which lead to financial data inclusion and thus financial inclusion, all falling under the umbrella of poverty reduction.

\subsection{Benefits of Financial Inclusion in Literature}

Many policy makers have emphasized that, although financial inclusion is a major contributor to economic growth, it is not the sole factor. According to a United Nations report in 2016, financial inclusion should "bring the poor into the formal economy" or in an informal manner. Economists Bruhn and Love (2014) state that financial inclusion should increase "the number of poor individuals [who] have the opportunity for financial access". Studies such as Malady (2016) find that increasing the number of official bank branches does not guarantee improved financial inclusion, because most banks do not target excluded communities such as rural areas as a key objective. Furthermore, the lack of a strong ICT system makes it rather difficult to target discriminated against groups in society such as women, the poor or uneducated people. De Koker and Jentzsch (2013) use Brazil as a case study to explain that the use of ICT is "instructive and progressive and able to deliver financial services to tens of millions of poor Brazilians". Findings on Sub-Saharan Africa from Demirguc-Kunt and Klapper (2015) corroborate the usefulness of ICT in enhancing financial inclusion.

In order for financial inclusion to achieve poverty reduction, a collaborative act between the public and private sector, specifically in emerging economies, needs to emerge. Direct government intervention should include the provision of welfare benefits to discriminated against social groups in society. Private sector players such as Fintech and other financial services companies should offer digital finance products and services to the poor and excluded population, to encourage them to participate in the formal financial sector through digital channels via their mobile phones. For instance, the CBE supported the Egyptian government in hosting the 2017 Alliance for Financial Inclusion Global Policy Conference, in which more than 94 States and 119 international institutions participated. As a result, the CBE and the National Council for Women (NCW) agreed to work jointly to foster women's financial inclusion (Financial Inclusion Through Digital Financial Services and Fintech: The Case of Egypt, 2018). 


\subsection{Financial Inclusion Determinants in Literature}

Several studies have shown a high correlation between the geographic presence of bank branches and the likelihood of account ownership among relatively low-income individuals. Economists Allen et al. (2016) conducted a study using data on 123 countries and over 124,000 individuals and established a dependent relationship between financial inclusion and an easily accessible environment offering financial services, such as lower banking costs, greater proximity to branches, stronger legal rights, political stability and fewer documentation requirements to open an account. Using the World Bank's 2017 Global Findex database, Zins and Weill (2016) conclude that, in Africa, financial inclusion determinants include higher education levels and higher income. Chithra \& Selvam (2013) give significance to the same financial determinants in India such as income, literacy, population, deposit and credit.

There are several individual characteristics that have an influence on the level of financial inclusion in Egypt, interchangeably referred to as determinants and explanatory, micro-determined variables. Figure 2 shows the relative percentages of individuals of 15 years or older opening a financial account. Egypt has $32.1 \%$ of its 15 or above population with bank accounts, much lower than the Gulf States, and just above countries like Iraq that have experienced political instability and have valid reasons for not having higher percentages.

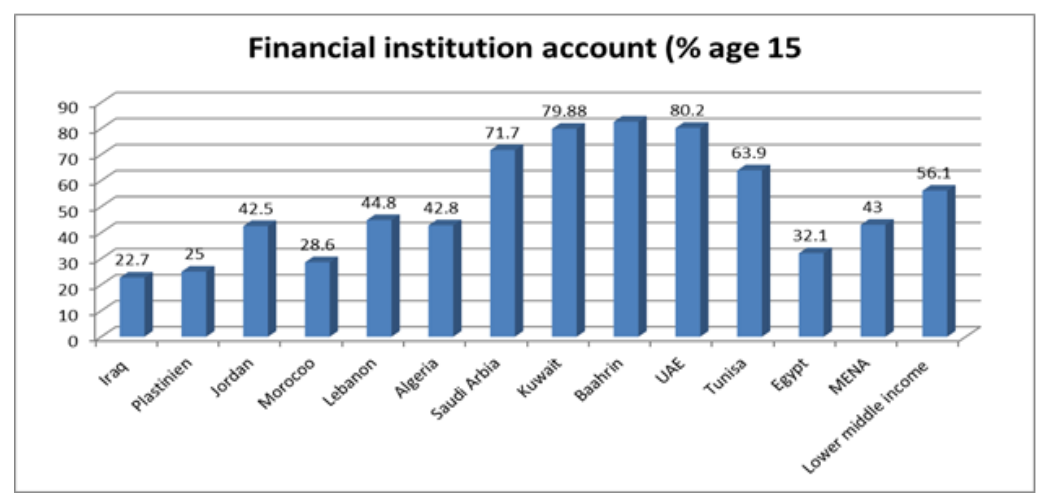

Figure 1. Financial institution accounts (\% of individuals 15 years or above)

Source: Global Findex Database 2018

\subsection{Gender Gap and Financial Inclusion in Literature}

Financial discrimination is affected by individual characteristics such as rich or poor, male or female, urban or rural. Economist Allen (2016) analyses individual characteristics on a global scale and finds that the probability of having an account at a formal financial institution is higher for richer, more educated, older, urban, employed, married or separated individuals. Studies conclude that there is no significant relationship between the physical presence of bank branches or ATMs and the frequency of use of accounts by female relatives of males. Recurrent barriers to financial services for those who are poor, less educated, unemployed, or rural residents are cost, and distance for rural residents. The likelihood of saving formally is higher for individuals with the same characteristics. Finally, the probability of borrowing formally increases for older, more educated, richer and married men. Using the 2012 Global Findex, Fungácová and Weill (2015) study financial inclusion in China and find that richer, more educated, older men are more likely to be financially included. Individual attitudes based on the "lack of" factor create certain barriers to financial inclusion, such as lack of money, lack of documentation, or lack of trust. Distance, high costs, documentation requirements and the lack of trust are involuntary self-exclusion barriers.

Most literature faultily generalizes that women are a handicapped group, with lower levels of education and fear of dealing with official documentation and inclusion. There should be a distinction between women who have unluckily not had the opportunity to become educated and women who are educated, and those who are unemployed and employed, and therefore financially included in the economy. In this paper, the focus is the less fortunate group of women, supporting the findings of Aterido (2013) that the existing gender gap in the financial sector is due to female participation in the economy but not within the financial sector itself. Women are discriminated against, as they take informal credit for granted and do not substitute it for formal credit. Using the 2012 Global Findex of 98 developing countries, Demirguc-Kunt et al. (2013) find that a significant gender gap exists in account ownership, formal savings and formal credit. Women face difficulties in becoming part of the financial system mainly due to financial illiteracy, 
a lack of documentation or personal guarantees, and the husband's adverse credit history. Moreover, African women are more likely to resort to informal financial services. Lenka (2016) provides evidence of country characteristics influencing financial inclusion. High quality institutions, efficient legal rules, strong contract enforcement and political stability all bring about financial inclusion. The existence of a deposit insurance scheme and tax incentive schemes also lead to greater financial inclusion. Swamy (2014) examines the impact of financial inclusion where women are the head household relative to the male head of the household. The study finds that income growth net of inflation effect is $8.40 \%$ for women against $3.97 \%$ for men, indicating that the gender of the individual participating undoubtedly affects the outcome.

The literature reviewed provides only a qualitative analysis of the topic of financial inclusion in Egypt and emerging countries in general. Existing literature discusses regional financial inclusion activities rather than individual country performance. This paper is significant because it establishes an explanation of the relationship between financial inclusion, financial inclusion indicators, and financial inclusion determinants in the country specific case of Egypt, using a quantitative approach. Recommendations for how Egypt could better engage in financial inclusion are also given.

\section{An Analysis of Egypt and Financial Inclusion}

\subsection{National Council for Payments and Financial Inclusion in Egypt}

With the launch of the National Council for Payments NCP (Note 1) in 2016, Egypt's plan for financial inclusion seemed attainable, but with the still challenging step of gradually transforming the economy to a cashless one. The NCP's main aim is to ensure access to financial services for all citizens, specifically women and youth, by: (1) reducing the use of banknotes outside the banking system; (2) motivating electronic payments; and (3) modernizing national payment systems. This, in an ideal world, would boost economic growth and improve citizens' standards of living (Financial Development and Inclusion in Egypt, Jordan, Morocco, and Tunisia, 2018). The NCP works to ensure that the process of financial inclusion is successfully implemented first by the government and then by its citizens. Governmental transactions that are more than EGP20,000 should be done using bank checks. Public services should offer citizens the option of non-cash international payment systems (CBE, 2017). The NCP has also advised governmental bodies to issue a national payment card, the "National Card Scheme" that citizens could use to pay for governmental services.

\subsection{Central Bank of Egypt and Financial Inclusion}

The status of financial inclusion in Egypt can be explained by the actions of the financial regulatory bodies such as the Central Bank of Egypt (CBE) and the Egyptian Financial Regulatory Authority (FRA). The CBE is the supervisor and monetary policy dictator of all commercial and specialized banking institutions as well as non-banking institutions such as investment banks, the stock market, microfinance, insurance, etc. (FRA, 2019). In Table 1, the actual steps taken by the CBE to grow financial inclusion are summarized.

Table 1. Central bank of Egypt and tools for enhancing financial inclusion

\begin{tabular}{ll}
\hline $\begin{array}{l}\text { CBE Tool for Financial } \\
\text { Inclusion }\end{array}$ & CBE Objective \\
\hline Use of Mobile Wallets & $\begin{array}{l}\text { Focuses on government social pensions, credit disbursements and monthly } \\
\text { payments to/from borrowers (microfinance institutions). }\end{array}$ \\
\hline Cardless ATMs & Provides cash-in/cash-out for mobile wallets. \\
\hline $\begin{array}{l}\text { International Money } \\
\text { Transfers (IMT) }\end{array}$ & Receive IMT into m-wallets. \\
\hline $\begin{array}{l}\text { Village Savings and Loans } \\
\text { Associations (VSLA) }\end{array}$ & $\begin{array}{l}\text { Enables participants to organize themselves into informal savings and credit } \\
\text { groups to accumulate savings of more than EGP4.5 million. VSLA members use } \\
\text { their own group savings to access loans. }\end{array}$ \\
\hline $\begin{array}{l}\text { Fast-Moving Consumer } \\
\text { Goods (FMCG) }\end{array}$ & $\begin{array}{l}\text { Eases the spread of digital payments as both customers and merchants begin to } \\
\text { make and collect payments through their m-wallets. }\end{array}$ \\
\hline $\begin{array}{l}\text { Mobile Merchant Payment } \\
\text { QR codes }\end{array}$ & $\begin{array}{l}\text { Transfers funds between customers to withdraw and convert to cash in a } \\
\text { transitional stage that prepares users to store funds in their wallets. Merchants } \\
\text { with QR codes complete all consumer transactions. Consumers scan the }\end{array}$ \\
\hline
\end{tabular}


merchant's account on their smartphone for a notification of the transaction detail.

\begin{tabular}{ll}
\hline Nano-finance & $\begin{array}{l}\text { Directs mobile money customers to request instant, low value emergency loans } \\
\text { set according to the credit scoring algorithm of the I score. }\end{array}$
\end{tabular}

New Regulations for Transfers funds and remittances via mobile accounts.

Mobile Payments

Source: Table constructed by the authors with data from Facilitating Bank Account Transactions: Steps Towards Financial Inclusion in Egypt, Policy Recommendations (2017) Federation of Egyptian Banks FEB and Federation of Egyptian Industries, September 2017, pp.1-48.

\subsection{Financial Inclusion Indicators in Egypt}

Based on the Global Findex database, this paper summarizes the indicators of financial inclusion in Figure 2.

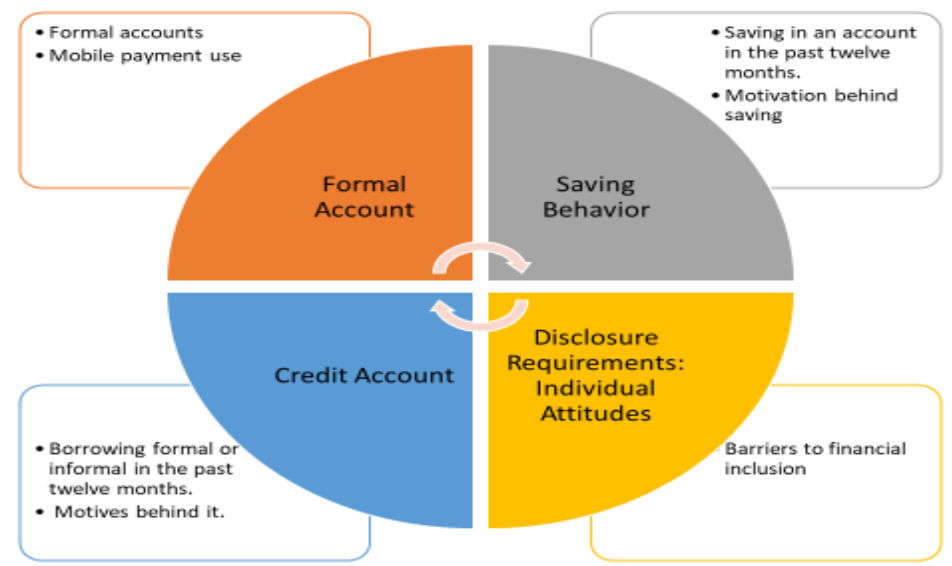

Figure 2. Indicators of financial inclusion in Egypt

Source: Figure constructed by the authors based on World Bank Global Findex Data.

In this context, a formal account is an individual account belonging to a financial institution or a mobile provider; formal saving is an individual account used for saving purposes in the past 12 months; and formal credit is individual borrowing from a financial institution in the past 12 months.

\section{Data}

The World Bank's Global Findex Database 2017 is used in this paper to analyse Egypt's financial inclusion, as it brings together various indicators of financial inclusion such as the level of access, amount of account penetration, use of financial services, and the purposes, motivations and alternatives to formal finance. It provides micro-level information such as gender, age, income and education, all of which are used in our estimations. The Fintech revolution presents key findings from the Global Findex database, with detailed insight into how adults in more than 140 economies access accounts, make payments, save, borrow, and manage risk. The data is collected in partnership with Gallup Inc., through nationally representative surveys of more than 150,000 adults in over 144 economies. A total sample size of 1,000 individuals is used, focusing on the three main measures of financial inclusion: formal accounts, formal savings, and credit accounts. Along with explaining the barriers to financial inclusion, individuals were asked: "Which of the following would be a reason for you for not having a bank account or any other form of formal institutional account?" All the variables listed are dummies, equal to one if the response is 'yes' and zero if 'no'. Tables 2 and 3 show descriptive statistics for the individual characteristics in Egypt for the dependent variables of financial inclusion. 
Table 2. Descriptive statistics for the individual characteristics in Egypt

\begin{tabular}{|c|c|c|}
\hline \multirow[t]{2}{*}{ Gender } & Male $\mathrm{N}(\%)$ & $562(56.2 \%)$ \\
\hline & Female N(\%) & $438(43.8 \%)$ \\
\hline \multirow[t]{3}{*}{ Education level } & Completed primary or less $\mathrm{N}(\%)$ & $407(40.7 \%)$ \\
\hline & Secondary & $465(46.5 \%)$ \\
\hline & Completed tertiary or more & $128(12.8 \%)$ \\
\hline \multirow[t]{2}{*}{ Workforce } & Out of workforce & $507(50.7 \%)$ \\
\hline & In workforce & $493(49.3 \%)$ \\
\hline \multirow{5}{*}{$\begin{array}{l}\text { Within-economy } \\
\text { income quintile }\end{array}$} & Poorest $20 \%$ & $170(17 \%)$ \\
\hline & Second $20 \%$ & $179(17.9 \%)$ \\
\hline & Middle 20\% & $203(20.3 \%)$ \\
\hline & Fourth $20 \%$ & $217(21.7 \%)$ \\
\hline & Richest $20 \%$ & $231(23.1 \%)$ \\
\hline \multirow[t]{3}{*}{ Age } & $\mathrm{N}$ & 1000 \\
\hline & Mean & 39.8 \\
\hline & Standard deviation & 14.8 \\
\hline
\end{tabular}

Source: Table constructed by the authors for the main individual characteristics of financial inclusion

Table 2 shows that $56.2 \%$ of the Egyptian sample was male and $43.8 \%$ female. The male and female percentages are relatively incomparable with insignificant percentage differences, proving that there is no significant relationship between gender and levels of financial inclusion. The educational level of respondents, people aged 15 or above, gives alarming concern as $40.7 \%$ completed primary or less, $46.5 \%$ secondary and only $12.8 \%$ tertiary or above. The figures show $50.7 \%$ of the respondents to be out of the workforce while $49.3 \%$ are in the workforce. There is a negligible difference in the percentage of the people in the workforce and out of it, which could be due to unemployment or factors such as custom and tradition when it comes to females being allowed to play an active role in the workforce. The within-economy household income is categorized into five quintiles, the poorest represents $17 \%$ of the sample and the richest represents $23.1 \%$. The top $40 \%$ richest population constitute $44.8 \%$ of the sample, while middle-income individuals constitute $20.3 \%$ and the poorest $34 \%$. In addition, there is a variety in age, with the mean age being 39.8 years and the standard deviation being 14.8 .

Table 3 shows that the main indicators of financial inclusion in Egypt have not yet gained momentum, with 29.4\% individuals opening a formal account in a financial institution, a surprising $6.2 \%$ of individuals saving money at a formal institution in the past 12 months and 3.5\% of individuals prioritizing formal credit. Table 3 shows a low level of financial literacy in Egypt, with the vast majority of the sample tested neglecting the need to be financially included, with $70.6 \%$ not having a formal account, $93.8 \%$ not having a savings account, and $96.4 \%$ not having a formal credit account. Financial literacy is defined as "a combination of the awareness, knowledge, skills, attitude and behaviours necessary to make sound financial decisions and ultimately achieve individual financial wellbeing" (Atkinson and Messy, 2012, p.14). Being financially literate is a process of gaining the skills and ability as a household or business in order to comprehend the various financial services provided and make use of them in the best self-interest, be that loans, deposits, or a calculation of interest rates paid to the bank or given by the bank. In reality, according to the statistics shown in Table 3, Egyptian citizens lack knowledge, confidence and awareness of the importance of being financially included.

For remittances, $90.9 \%$ of the sample had not sent a domestic remittance to a formal financial institution in the past 12 months. The respondents were asked about their saving motivation and given two options, farm business and old age. $95.3 \%$ of the sample did not consider farm business a saving motivation and $95.8 \%$ did not consider old age a saving motivation. These indicators show that respondents either do not have enough money to put into a formal account or are unaware of the benefits of keeping their money in a formal financial account. 
Table 3. Descriptive analysis of the dependent variables

\begin{tabular}{|c|c|c|c|}
\hline \multicolumn{2}{|l|}{ Formal inclusion } & \multirow{2}{*}{$\begin{array}{l}\text { Frequency } \\
706\end{array}$} & \multirow{2}{*}{$\begin{array}{l}\text { Percentage (Mean) } \\
70.60 \%\end{array}$} \\
\hline Eormal scount & No & & \\
\hline Formal account & yes & 294 & $29.40 \%$ \\
\hline \multirow{2}{*}{ Formal savings } & No & 938 & $93.80 \%$ \\
\hline & yes & 62 & $6.20 \%$ \\
\hline \multirow{2}{*}{ Formal credit } & No & 962 & $96.49 \%$ \\
\hline & yes & 35.1 & $3.51 \%$ \\
\hline Barriers & & Frequency & Percentage (Mean) \\
\hline \multirow{2}{*}{ Too far away } & No & 615 & $93.18 \%$ \\
\hline & Yes & 45 & $6.82 \%$ \\
\hline \multirow{2}{*}{ Expensive } & No & 536 & $81.71 \%$ \\
\hline & Yes & 120 & $18.29 \%$ \\
\hline \multirow{2}{*}{ Lack of documentation } & No & 583 & $88.47 \%$ \\
\hline & Yes & 76 & $11.53 \%$ \\
\hline \multirow{2}{*}{ Lack of trust } & No & 629 & $89.22 \%$ \\
\hline & Yes & 30 & $4.26 \%$ \\
\hline \multirow[b]{2}{*}{ Religious reasons } & No & 632 & $95.32 \%$ \\
\hline & Yes & 31 & $4.68 \%$ \\
\hline \multirow{2}{*}{ Lack of money } & No & 95 & $14.35 \%$ \\
\hline & Yes & 567 & $85.65 \%$ \\
\hline \multirow{2}{*}{ Family member already has one } & No & 610 & $92.15 \%$ \\
\hline & Yes & 52 & $7.85 \%$ \\
\hline \multirow{2}{*}{ No need for financial services } & No & 441 & $66.92 \%$ \\
\hline & Yes & 218 & $33.08 \%$ \\
\hline Remittance & & Frequency & Percentage (Mean) \\
\hline \multirow{2}{*}{ Sent domestic remittance in the past 12 months } & No & 909 & $90.99 \%$ \\
\hline & yes & 90 & $9.01 \%$ \\
\hline Saving Motivation & & Frequency & Percentage (Mean) \\
\hline \multirow{2}{*}{ Farm business } & No & 953 & $95.40 \%$ \\
\hline & Yes & 46 & $4.60 \%$ \\
\hline \multirow{2}{*}{ Old age } & No & 958 & $95.80 \%$ \\
\hline & Yes & 42 & $4.20 \%$ \\
\hline Informal saving & & Frequency & Percentage Mean \\
\hline \multirow{2}{*}{$\begin{array}{l}\text { Saved in past } 12 \text { Months using an informal } \\
\text { account }\end{array}$} & No & 842 & $84.20 \%$ \\
\hline & Yes & 158 & $15.80 \%$ \\
\hline
\end{tabular}

Source: Table constructed by the authors.

\section{Methodology}

In order to evaluate the determinants of financial inclusion, logistic regression is used:

$$
\log \left(\frac{P\left(X_{i}=1\right)}{1-P\left(X_{i}=1\right)}\right)=\alpha+\beta_{1} * \text { gender }+\beta_{2} \text { Age }+\beta_{3} \text { Income }+\beta_{4} * \text { Education }
$$


Where $X$ is the financial inclusion variable and $i$ represents one individual. The individual characteristics are the explanatory variables. Gender is a dummy variable equal to one if the individual is a woman (Female) and zero if else. Age is represented by two measures, number of years $(A g e)$ and its square $\left(A g e^{2}\right)$, in order to control for a possible non-linear relationship between age and financial inclusion. The results of various models are shown in the following tables. Usually, if the p-value is smaller than 0.05 the factor can be considered significant at $95 \%$ significance level, assuming the other factors are held constant.

\section{Results}

\subsection{Determinants of the Three Main Financial Inclusion Indicators}

Table 4. Logistic regression of the main indicators of financial inclusion in Egypt

\begin{tabular}{|c|c|c|c|}
\hline & Formal Account & Formal Savings & Formal Credit \\
\hline \multirow{2}{*}{ Age } & $0.102303^{* * *}$ & 0.038463 & $0.192636^{* * *}$ \\
\hline & $(0.003)$ & $(0.516)$ & $(0.054)$ \\
\hline \multirow{2}{*}{$\operatorname{Age}^{2}$} & -0.00034 & -0.00038 & -0.00209 \\
\hline & $(0.377)$ & $(0.581)$ & $(0.076)$ \\
\hline \multirow{2}{*}{ Secondary } & $0.499139^{* * *}$ & -0.02114 & 0.644493 \\
\hline & $(0.01)$ & $(0.954)$ & $(0.222)$ \\
\hline \multirow{2}{*}{ Completed tertiary or more } & $1.111791^{* * *}$ & $1.210585^{* * *}$ & $1.55558^{* * *}$ \\
\hline & $(0.000)$ & $(0.002)$ & $(0.005)$ \\
\hline \multirow{2}{*}{ Female } & -0.1167 & -0.64231 & $0.783128^{* * *}$ \\
\hline & $(0.547)$ & $(0.074)$ & $(0.059)$ \\
\hline \multirow{2}{*}{ Second $20 \%$} & 0.107687 & 0.372503 & -1.16696 \\
\hline & $(0.714)$ & $(0.572)$ & $(0.316)$ \\
\hline \multirow{2}{*}{ Middle 20\% } & 0.249207 & 0.674384 & 0.646679 \\
\hline & $(0.365)$ & $(0.263)$ & $(0.348)$ \\
\hline \multirow{2}{*}{ Fourth $20 \%$} & $0.66542^{* * *}$ & 0.467829 & -0.62447 \\
\hline & $(0.012)$ & $(0.443)$ & $(0.458)$ \\
\hline \multirow{2}{*}{ Richest $20 \%$} & $0.724192^{* * * *}$ & $1.510345^{* * * *}$ & $1.345322^{* * *}$ \\
\hline & $(0.007)$ & $(0.007)$ & $(0.041)$ \\
\hline \multirow{2}{*}{ In the work force } & \multirow{2}{*}{0.250843} & 0.222807 & $1.178433^{* * *}$ \\
\hline & & $(0.543)$ & $(0.016)$ \\
\hline Constant & -5.42077 & -4.54084 & -9.50951 \\
\hline Observations & 1000 & 1000 & 1000 \\
\hline Log likelihood & 211.9 & 52.6 & 62.5 \\
\hline Pseudo $\mathrm{R}^{2}$ & 0.175 & 0.1132 & 0.1935 \\
\hline
\end{tabular}

$* * *$ Significance at the $1 \%$ level, $* *$ Significance at the $5 \%$ level

Source: Table constructed by the authors.

In Table 4, formal account, formal savings and formal credit are the dependent variables. The results reveal that not all the individual characteristics have a significant relation to financial inclusion. Age has a nonlinear relationship, positive and significant, with having a formal account and a credit account. Ironically, $\boldsymbol{A g e}^{2}$ proves insignificant, indicating the carelessness of old Egyptians with regards to financial institutions. As for Education, the higher the 
educational level of the individual, the more significant financial inclusion becomes. Individuals with a secondary education are aware of the importance of owning and opening a formal account, as shown by the positive coefficient associated only with the formal account. This is in agreement with Allen et al. (2016) and Fungáčová \& Weill (2015) that being richer and more educated is more likely to lead to being financially included. The higher the income of an Egyptian individual progressively, the higher the level of financial inclusion. The results show that the lower income group do not recognise the importance or are not financially aware of the significance of the three indicators of financial inclusion. The highest income individuals constituting the top $20 \%$ of the sample are financially aware of the three indicators; the next highest income group are aware of the positive effects of opening a formal account with a financial institution. As for gender, Egypt's results are consistent with those of Allen et al. (2016), that there is no significant relationship between gender and financial inclusion. Being in the workforce is positively associated with having a formal account. In a nutshell, the results reveal that an individual with high progressive income and high educational level have a higher level of financial literacy and awareness and favour access to financial services in Egypt. Age also increases the tendency to use formal credit, with a 95\% confidence level.

\subsection{Determinants of Barriers to Financial Inclusion}

In this section, individual characteristics and their impact on financial inclusion are discussed. A regression estimation of the eight barriers to financial inclusion is summarized in Table 5 below.

Table 5. Regression estimation of the barriers to financial inclusion in Egypt

\begin{tabular}{|c|c|c|c|c|c|c|c|c|}
\hline & $\begin{array}{l}\text { Too far } \\
\text { away }\end{array}$ & Expensive & $\begin{array}{l}\text { Lack of } \\
\text { document } \\
\text { ation }\end{array}$ & $\begin{array}{l}\text { Lack of } \\
\text { trust }\end{array}$ & $\begin{array}{l}\text { Religious } \\
\text { reasons }\end{array}$ & $\begin{array}{l}\text { Lack of } \\
\text { money }\end{array}$ & $\begin{array}{l}\text { Family } \\
\text { member } \\
\text { already } \\
\text { has one }\end{array}$ & $\begin{array}{l}\text { No need } \\
\text { for } \\
\text { financial } \\
\text { services }\end{array}$ \\
\hline \multirow[t]{2}{*}{ Age } & 0.027 & 0.0476 & -0.045 & -0.106 & -0.059 & 0.0743 & $-0.116 * * *$ & 0.004 \\
\hline & (0.674) & $(0.243)$ & $(0.329)$ & $(0.13)$ & $(0.403)$ & (0.084) & (0) & (0.907) \\
\hline \multirow[t]{2}{*}{$\mathrm{Age}^{2}$} & $-6 \mathrm{E}-04$ & $-4 \mathrm{E}-04$ & 0.0003 & 0.001 & 0.0008 & -9E-04 & 0.0012 & $-2 \mathrm{E}-06$ \\
\hline & $(0.51)$ & $(0.424)$ & $(0.562)$ & $(0.259)$ & $(0.401)$ & $(0.082)$ & $(0.1)$ & (0.996) \\
\hline \multirow[t]{2}{*}{ Secondary } & -0.486 & 0.257 & 0.0896 & 0.5064 & $0.9477 * *$ & -0.128 & 0.6296 & 0.15 \\
\hline & $(0.151)$ & $(0.26)$ & $(0.746)$ & $(0.229)$ & $(0.038)$ & $(0.637)$ & $(0.1)$ & $(0.436)$ \\
\hline \multirow{2}{*}{$\begin{array}{l}\text { Completed } \\
\text { tertiary or } \\
\text { more }\end{array}$} & -0.151 & -0.488 & -1.085 & -0.212 & -0.38 & $-1.111 * * *$ & 0.6031 & 0.506 \\
\hline & $(0.781)$ & $(0.274)$ & $(0.091)$ & $(0.795)$ & $(0.728)$ & $(0.003)$ & $(0.3)$ & $(0.097)$ \\
\hline \multirow[t]{2}{*}{ Female } & -0.173 & -0.211 & -0.398 & -0.383 & 0.062 & 0.0091 & 0.6937 & 0.23 \\
\hline & $(0.663)$ & $(0.42)$ & $(0.192)$ & $(0.388)$ & $(0.892)$ & $(0.975)$ & $(0.1)$ & $(0.29)$ \\
\hline \multirow[t]{2}{*}{ Second 20\% } & 0.0278 & 0.1174 & -0.44 & 0.0123 & 0.1509 & $-0.721 * *$ & -0.293 & 0.008 \\
\hline & (0.949) & $(0.69)$ & $(0.266)$ & (0.984) & $(0.761)$ & $(0.051)$ & $(0.5)$ & $(0.973)$ \\
\hline \multirow[t]{2}{*}{ Middle $20 \%$} & -0.3 & -0.16 & -0.015 & 0.5566 & -0.795 & -0.426 & -0.082 & -0.23 \\
\hline & $(0.536)$ & $(0.605)$ & $(0.968)$ & $(0.336)$ & $(0.207)$ & $(0.271)$ & (0.9) & $(0.369)$ \\
\hline \multirow[t]{2}{*}{ Fourth $20 \%$} & -0.014 & -0.387 & -0.577 & 0.3951 & -0.358 & -0.479 & -0.207 & -0.26 \\
\hline & $(0.976)$ & $(0.237)$ & $(0.177)$ & $(0.506)$ & $(0.525)$ & $(0.21)$ & $(0.7)$ & $(0.323)$ \\
\hline \multirow[t]{2}{*}{ Richest 20\% } & -0.133 & -0.083 & 0.6341 & 0.4075 & -0.63 & -0.165 & 0.516 & -0.02 \\
\hline & $(0.79)$ & $(0.8)$ & $(0.081)$ & $(0.51)$ & $(0.329)$ & (0.687) & $(0.2)$ & $(0.934)$ \\
\hline \multirow[t]{2}{*}{ In workforce } & -0.132 & -0.144 & $-0.739 * *$ & -0.025 & -0.184 & 0.2976 & -0.052 & -0.03 \\
\hline & $(0.744)$ & $(0.588)$ & $(0.02)$ & (0.954) & $(0.7)$ & (0.319) & $(0.9)$ & $(0.886)$ \\
\hline
\end{tabular}




\begin{tabular}{lllllllll}
\hline constant & $-2.249^{* *}$ & $-2.394 * * *$ & -0.324 & -1.088 & -2.22 & 0.9594 & -0.847 & -0.94 \\
& $(0.056)$ & $(0.003)$ & $(0.711)$ & $(0.392)$ & $(0.097)$ & $(0.253)$ & $(0.4)$ & $(0.148)$ \\
\hline Observations & 100 & 100 & 100 & 100 & 100 & 100 & 100 & 100 \\
\hline Log & -172.8 & -320.05 & -232.144 & -130.766 & -122.58 & -264.35 & -175.2 & -420.34 \\
likelihood & & & & & & & & \\
\hline Pseudo R & 0.016 & 0.0168 & 0.0573 & 0.0459 & 0.0433 & 0.031 & 0.0643 & 0.0082 \\
\hline
\end{tabular}

Source: Table constructed by the authors.

*** Significance at the $1 \%$ level, $* *$ Significance at the $5 \%$ level

Table 5 is a simulation that shows that gender has no impact on being financially included. This is parallel to the global context, where there is no significant relationship between gender and the level of financial inclusion. Nevertheless, inequality still remains a barrier because women are excluded from being in the financial system due to their insufficient funds and the societal perception that the male is the dominant figure and main breadwinner in the household not the female, and thus their financial data is not included in financial systems.

Unlike most African countries where aging individuals have no barrier of lack of money, the most significant barrier for financial inclusion in Egypt is lack of money. In Africa, mature and aged individuals have other issues to deal with such as distance, cost, trust and religion (Zins \& Laurent, 2016). For Egypt, lack of money, at a confidence level of $90 \%$, constitutes the biggest barrier for the older generation, while distance, cost, lack of documentation, trust, and family members with existing accounts are insignificant obstacles. This is an indication that there are other external, macroeconomic factors, based on economic and human development, that need to be addressed in Egypt in order for financial inclusion to be achieved.

Education follows age, with the same barriers; lack of money represents the only major barrier to financial inclusion. For lower income individuals, lack of money is the main barrier, unlike high income people who have no barriers to financial inclusion. The result of being in the workforce is interesting; lack of documentation presents a significant barrier to financial inclusion, emphasizing that the process of being financially included is not easily understood. Individuals have difficulty comprehending the language of financial services as they are offered and marketed, mainly due to the complicated terminology used by financial institutions and a lack of financial literacy. Due to the political and economic turbulence that Egypt has witnessed over the last decade, lack of money also represents a major barrier to inclusion regardless of age, gender, or education.

\subsection{Understanding Saving Behaviour}

Analysing saving behaviour in Egypt is directly related to the motives behind formal and informal saving, whether saving behaviour is for business, for old age, or for any other individual reason. Primarily, being in the workforce is crucial to saving for a business, with a significant p-value of 0.002 , as evident in Table 6 . Tables 5 and 6 show that older Egyptians tend to save in informal ways, with a p-value of 0.004 , usually under their pillows at their own homes. The results of the survey question: "in the past 12 months, have you, saved or set aside any money by using an informal saving group/club or person outside the family?" show more negative coefficients for older ages.

Being a woman implies a low probability of saving for the three reasons, the main barrier being lack of money. Women can barely save either for a start-up business $(-42 \%)$ or for securing their financial status in old age (-13\%). Therefore, there is a significant relationship between saving behaviour and gender, however it is insignificant in the context of the financial inclusion indicators. This could again be a cultural matter.

For income, being poorer decreases the probability of saving, for any of the three motivations. The richest $20 \%$ mainly save for the motives of opening a business and old age and retirement.

Table 6. Determinants of saving motivation in Egypt

\begin{tabular}{|c|c|c|c|}
\hline & $\begin{array}{l}\text { Saving motivation: } \\
\text { business }\end{array}$ & $\begin{array}{l}\text { Saving motivation: } \\
\text { old age }\end{array}$ & Informal Saving \\
\hline \multirow[t]{2}{*}{ Age } & -0.016 & 0.0467 & $0.0233^{* *} *$ \\
\hline & $(0.808)$ & $(0.459)$ & $(0.036)$ \\
\hline
\end{tabular}




\begin{tabular}{llll}
\hline Age $^{2}$ & 0.0001 & $-1 \mathrm{E}-04$ & $-4 \mathrm{E}-04 * * *$ \\
& $(0.87)$ & $(0.879)$ & $(0.0004)$ \\
\hline Secondary & 0.3566 & 0.2608 & 0.3123 \\
& $(0.346)$ & $(0.517)$ & $(0.2117)$ \\
\hline Completed tertiary or more & -0.147 & 0.6632 & 0.1424 \\
& $(0.782)$ & $(0.179)$ & $(0.2995)$ \\
\hline Female & -0.424 & -0.138 & 0.2897 \\
& $(0.328)$ & $(0.723)$ & $(0.2201)$ \\
\hline Second 20\% & 0.0257 & 0.6648 & 0.6356 \\
& $(0.967)$ & $(0.355)$ & $(0.3521)$ \\
\hline Middle 20\% & 0.53 & 1.0927 & 0.8705 \\
\hline Fourth 20\% & $(0.343)$ & $(0.098)$ & $(0.3371)$ \\
\hline Richest 20\% & -0.114 & -0.156 & 0.7359 \\
& $(0.851)$ & $(0.841)$ & $(0.3395)$ \\
\hline In the workforce & 0.9311 & 1.1162 & 1.0789 \\
& $(0.085)$ & $(0.089)$ & $(0.3358)$ \\
\hline Constant & $1.4519 * * *$ & 0.1183 & 0.3946 \\
\hline Observations & $(0.002)$ & $(0.773)$ & $(0.2301)$ \\
\hline Log likelihood & -4.005 & -5.873 & -3.184 \\
\hline Pseudo R ${ }^{2}$ & 1000 & 1000 & 1000 \\
\hline
\end{tabular}

*** Significance at the $1 \%$ level, ** Significance at the $5 \%$ level

\subsection{Determinants of Remittances}

In Table 7, individuals with higher educational levels are shown to have sent domestic remittances in the past 12 months using a formal financial account system more than individuals with education less than secondary, with a confidence level of $95 \%$ ( $p$-value smaller than 0.05 ), fixing all other factors.

As for income, individuals in the fourth quintile according to the within-economy household income have a higher tendency to have sent domestic remittances in the past 12 months than the poorest people, with a confidence level of 95\% (p-value smaller than 0.05) fixing all other variables. As expected, the richest people have a higher tendency to send domestic remittances in the past 12 months than the poorest people, with a confidence level of $95 \%$ (p-value smaller than 0.05) fixing all other variables.

Table 7. Determinants of remittances

\begin{tabular}{ll}
\hline & Coefficient \\
\hline Age & 0.0536 \\
& $(0.319)$ \\
\hline Age $^{2}$ & $-8 \mathrm{E}-04$ \\
& $(0.228)$ \\
\hline Secondary & $1.012 * * *$ \\
& $(0.003)$ \\
\hline
\end{tabular}




\begin{tabular}{ll}
\hline Completed tertiary or more & $1.5307 * * *$ \\
& $(0.00)$ \\
\hline Female & -0.512 \\
& $(0.089)$ \\
\hline Second 20\% & 0.5186 \\
& $(0.367)$ \\
\hline Middle 20\% & 0.5256 \\
& $(0.34)$ \\
\hline Fourth 20\% & $1.0649 * *$ \\
& $(0.039)$ \\
\hline Richest 20\% & $1.764 * * *$ \\
& $(0.00)$ \\
\hline In the workforce & 0.235 \\
& $(0.442)$ \\
\hline Constant & -4.826 \\
\hline Observations & 100 \\
\hline Log likelihood & -264.7 \\
\hline Pseudo R & 0.1316
\end{tabular}

Source: Table constructed by the authors.

*** Significance at the $1 \%$ level, ** Significance at the $5 \%$ level

\section{Conclusion}

Egypt has low financial inclusion in comparison to the rest of the world, even Africa. In order to become part of the global economy and achieve its digital financial evolution, financial inclusion should be implemented as a prerequisite, to ensure poverty alleviation and boost economic growth. We conclude that financial inclusion is a process that involves access to financial services for low income financially excluded groups. In this paper, the natures of the determinants of financial inclusion in Egypt are investigated through a sample of 1,000 individuals.

The two main barriers that need to be overcome in order for financial inclusion to be achieved are: (1) lack of money; and (2) financial illiteracy. A lack of money is actually a major crisis for individuals as it handicaps them from consumption, saving, and investment. A lack of money is an indicator of poverty in Egypt. The findings support the fact that policies favouring financial inclusion should target all groups, men, women, and the young population. The analysis of saving motivations highlights the main barrier to financial inclusion in Egypt, a lack of money. A lack of documentation and financially illiteracy are only barriers to the highest income individuals when it comes to being financially included.

This paper could be used to design a national policy framework, as it pinpoints the major obstacles that a country such as Egypt should tackle in order to foster financial inclusion.

\section{Recommendations and Policies}

A progressive approach is needed to ensure that financial inclusion becomes embedded in the Egyptian economy. Two important prerequisites are increasing financial awareness and financial literacy among individuals for when the lack of money is no longer an obstacle. It is the government and central bank's role to direct investments into financial education campaigns, such as television advertisements, educational programmes, and extending the branches of banks to reach citizens in both urban and rural areas. 


\section{References}

Alexandria Bank. (2017). Financial Inclusion in Egypt.

Allen, F., Demirguc-Kunt, A., Klapper, L., \& Peria, M. S. M. (2016). The Foundations of Financial Inclusion: Understanding Ownership and Use of Formal Accounts. Journal of Financial Intermediation, 27(C), 1-30. https://doi.org/10.1016/j.jfi.2015.12.003

Aterido, R., Beck, T., \& Lacovone, L. (2013). Access to Finance in Sub-Saharan Africa: Is There a Gender Gap?. World Development, 47, 102-120. https://doi.org/10.1016/j.worlddev.2013.02.013

Atkinson, A., \& Messy, F. A. (2013). Promoting Financial Inclusion through Financial Education: OECD/INFE. Evidence, Policies and Practice. OECD Working Papers on Finance, Insurance and Private Pensions, no. 34. Paris: OECD Publishing.

Beck, T., \& Cull, R. (2015). Banking in Africa. In: Berger, A. N., Molyneux, P., \& Wilson J. O. S. (Eds.), The Oxford Handbook of Banking (pp. 913-937). Oxford University Press. https://doi.org/10.1093/oxfordhb/9780199688500.013.0037

Bruhn, M., \& Love, I. (2014). The Real Impact of Improved Access to Finance: Evidence from Mexico. Journal of Finance LXIX, 1347-1376. https://doi.org/10.1111/jofi.12091

DeKoker, L., \& Jentzsch, N. (2013). Financial Inclusion and Financial Integrity: Aligned Incentives?. World Development, 44, 267-280. https://doi.org/10.1016/j.worlddev.2012.11.002

Demirguc-Kunt, A., Klapper, L., Singer, D., \& Van Oudheusden, P. (2015). The Global Findex Database 2014. Measuring Financial Inclusion Around the World. Washington, DC: World Bank. https://doi.org/10.1596/1813-9450-7255

Digital Financial Services DFS Working Group. (2018). Financial Inclusion Through Digital Financial Services and Fintech: The Case of Egypt, pp. 1-12.

Eid, N., \& Awad, M. (2018). Financial Inclusion in the MENA Region: A Case Study on Egypt. IOSR Journal of Economics and Finance.

EMNES Studies. (2018, March 4). Financial Development and Inclusion in Egypt, Jordan, Morocco, and Tunisia, pp. 1-80.

Federation of Egyptian Banks FEB and Federation of Egyptian Industries. (2017, September). Facilitating Bank Account Transactions: Steps Towards Financial Inclusion in Egypt, Policy Recommendations, pp. 1-48.

Kapoor, A. (2013). Financial Inclusion and the Future of the Indian Economy. Futures, 56(2014), 35-42. https://doi.org/10.1016/j.futures.2013.10.007

Lenka, S. K., \& Barik, R. (2018). Financial Innovation. https://doi.org/10.1186/s40854-018-0089-x

Lenka, S. K., \& Bairwa, A. K. (2016). Does Financial Inclusion Affect Monetary Policy in SAARC Countries?. http://dx.dol.org/10.1080/23322039.2015.1127011

Malady, L. (2016). Consumer Protection Issues for Digital Financial Services in Emerging Markets. Banking \& Finance Law Review, 31(2), 389-401. https://doi.org/10.2139/ssrn.3028371

Mohieldin, M., Iqbal, Z., Rostom, A., \& Fu, X. (2011). The Role of Islamic Finance in Enhancing Financial Inclusion in Organization of Islamic Cooperation (OIC) Countries. World Bank. https://doi.org/10.1596/1813-9450-5920

Natarajan, C., \& Murugesan, S. (2013). Determinants of Financial Inclusion: An Empirical Study on the Inter-State Variations in India. http://dx.doi.org/10.2139/ssrn.2296096

Ozili, P. K. (2018), Impact of Digital Finance on Financial Inclusion and Stability. https://doi.org/10.1016/j.bir.2017.12.003

Sarma, M. (2015). Measuring Financial Inclusion. Economics Bulletin, 35, 604-611.

Swamy, V. (2014). Financial Inclusion, Gender Dimension, and Economic Impact on Poor Households. World Development, 56, 1-15. https://doi.org/10.1016/j.worlddev.2013.10.019

United Nations. (2016). Digital Financial Inclusion, International Telecommunication Union ITU, issue brief series, inter-agency task force on financing for development, July. Retrieved 12 August 2018 from http://www.un.org/esa/ffd/wp-content/uploads/2016/01/Digital-Financial-Inclusion_ITU_IATF-Issue-Brieft.pdf 
World Bank. (2012). World Development Indicators.

World Bank. (2014). Digital Finance: Empowering the Poor via New Technologies. Retrieved September 1, 2018, from

http://www.worldbank.org/en/news/feature/2013/03/10/digital-finance-empowering-poor-new-technologies

World Bank. (2015). World Development Indicators.

World Bank. (2018). World Development Indicators.

Zins, A., \& Laurent, W. (2016). The Determinants of Financial Inclusion in Africa. Review of Development Finance, 6. https://doi.org/10.1016/j.rdf.2016.05.001

\section{Note}

Note 1. The NCP's main goals focus on the development of a national payment system that secures reliable payments with low operational risk. Its main target is directing financial awareness, education, and financial services to the excluded groups by creating incentives to be financially included.

\section{Appendix}

Table 1. List of abbreviations

\begin{tabular}{ll}
\hline ATM & Automated Teller Machine \\
\hline CBE & Central Bank of Egypt \\
\hline FMCG & Fast-Moving Consumer Goods \\
\hline FRA & Financial Regulatory Authority \\
\hline ICT & Information and Communication Technologies \\
\hline NCP & National Council for Payments \\
\hline NCW & National Council for Women \\
\hline OECD & Organization for Economic Cooperation and Development \\
\hline SDS & Sustainable Development Strategy \\
\hline SME & Small and Medium Sized Enterprises \\
\hline VSLA & Village Savings and Loans Associations \\
\hline
\end{tabular}

